\title{
Economic development and Environmental quality: The environmental Kuznets curve for water pollution
}

\author{
AHMADREZA SHAHPOURI ${ }^{1}$, HAMED BIABI ${ }^{2}$, LEILI ABOLHASSANI $^{3}$ \\ ${ }^{l}$ PhD candidate of Agricultural Economics, Agricultural Sciences and Natural Resources University of Sari.Iran \\ ${ }^{2}$ MA of Agricultural Economics, Ferdowsi University of Mashhad. Iran \\ ${ }^{3}$ Assistant Professor of Agricultural Economics, Ferdowsi University of Mashhad.Iran \\ Coresponding author: * Ahmadreza Shahpouri.E-Mail: Ahmadreza.fm@gmail.com
}

\begin{abstract}
The main aim of this study was to analyze evidence of an environmental Kuznets curve for water pollution in the developing and developed countries. The study was conducted based on a panel data set of 54 countries - that were categorized into six groups of "developed countries", "developing countries", "developed countries with low income", "developed countries with high income" and "coastal countries"- between the years 1995 to 2006. The results do not confirm the inverted U-shape of EKC curve for the developed countries with low income. Based on the estimated turning points and the average GDP per capita, the study revealed at which point of the EKC the countries are. Furthermore, impacts of capital-and-labor ratio as well as trade openness are drawn by estimating different models for the EKC. The magnitude role of each explanatory variable on BOD was calculated by estimating the associated elasticity. (JASEM
\end{abstract}

http://dx.doi.org/10.4314/jasem.v20i1.19

KEYWORDS Economic Growth; Environmental Kuznets Curve; Developed countries; Developing countries; water pollution

\section{Introduction}

The Environmental Kuznet's Curve (EKC) hypothesis describes that economic growth declines the problems associated with environmental pollution. This relationship between income and environmental pollution is described as an inverted-U shape with a turning point presenting the income at which the environmental pollution reaches its maximum. Behind this hypothesis, a number of reasons associated with the economics of consumption and the economics of production have been described. For instance, from the consumption view, increased income may raise the demand for environmental quality. From the production view, increased income may change production from dirty goods such as manufactured products to clean goods such as services (Panayotou, 1993). Therefore, after the turning point of the EKC, the relationship between economic development and environmental quality turns out positive as the income increases.

Grossman 's study (Grossman and Krueger, 1995) was one of the initial work on the EKC by which the inverted U-shape curve was confirmed. Since then, the impact of increased economic activities such as increased income and trade openness on the environment became so interesting topic that a large number of studies, using different indicators for both economic activities and environmental pollution, has been conducted (Beron and Murdoch, 2003; Cole and Elliott 2003; Cole, 2004).
One of the famous study on the EKC relationship was conducted by (Antweiler and Copeland, 2001) by which determinants of emissions were decomposed into scale, technique, and composition effect. The scale effect reflexes the direct effect of the increased production on emissions. The technique effect indicates that demands for environmentally friendly products raises as income increases. This promotes employment of more environmentally friendly production methods that causes a reduction in emission intensity. The composition effects presents how an increased income affects the structure of the industry that itself influences the pollution intensity. Following up with developing the theoretical framework associated with the three effects, the study estimated each of the three presented effects on the SO2 concentration. The study concluded a positive scale effect, a negative composition effect, and a negative technique effect for the impact of trade openness on the SO2 emission. Another study (Managi and Akira, 2009) that worked on the overall impact of trade openness on the environmental quality found the EKC relationship is larger in the long term than that in the short term. The study also described that the magnitude of this relationship depends on the country and the pollutant. The environmental Kuznets curve was also confirmed for the two sub-groups of countries that share river on their border and those without river on their borders (Thompson, 2014). There are some other studies criticizing the EKC relationship. For instance, the study conducted by (Stern, 2004) argued that the 
EKC relation depends on the existence of some assumptions including normal distribution of income per capita. The EKC relationship between real income and biological oxygen demand (BOD) pollutants was also examined at a global scale(ChienChiang and Yi-Bin, 2010). The study concluded that the different regions have different EKC relationship. For instance, in America and Europe the inverted Ushaped EKC exists, while this has been rejected in Africa, Asia and Oceania.

Considering the significant role of regions on the EKC relationship and shape, the EKC curve should have different shape in the developing and the developed countries. If the hypothesis of different shape in different regions can not be rejected, policies towards environmental improvement should be differently designed with consideration to the associated EKC relationship of that region. The hypothesis of different shapes of EKC curve for developed and developing countries are examined in this study. The study definition of developed and developing countries is based on the human development index (HDI) that is a composition of life expectancy, education, and income indices. The study examines the scale effect, the composition effect and the impact of the trade openness on water pollution as a major concern in many developed and developing countries around the world.

\section{MATERIALS AND METHOD}

To conduct the study, annual data sets for 54 countries between the years 1995 to 2006 was collected. Based on the Human Development Index (HDI) reported by the World Bank in 2010, we divided the study countries into the two groups of developed countries and developing countries. For each country, data on Biochemical Oxygen Demand (BOD) as a proxy for water pollution, GDP per capita, the capital-and-labor ratio as a proxy for composition effect and degree of trade openness were collected. Summaries of the collected data for the described variables in the developed and developing countries are presented in the table 1and the table 2, separately. The following figures present averages of GDP per capita during the years 1995 to 2006 for each country in the group of the developing countries (Figure 1) and the countries in the group of the developed countries (Figure2).

Table1. Data description for the developed countries

\begin{tabular}{lccccc}
\hline Variable & Obs & Mean & Std. Dev & Min & Max \\
\hline$B O D_{i t}$ & 336 & 307088 & 498685.7 & 3355.436 & $\mathbf{2 6 5 5 3 6 4}$ \\
$G D P_{i t}$ & 336 & 24355.6 & 13362.3 & 2629.017 & $\mathbf{9 0 0 1 5 . 5 3}$ \\
$(K / L)_{i t}$ & 336 & 11103.8 & 5961.056 & 1519.009 & $\mathbf{4 0 6 5 0 . 1}$ \\
$T_{i t}(\%)$ & 336 & 1.044 & 0.7222 & 0.167 & $\mathbf{4 . 3 7 3}$ \\
& & & & & \\
\hline
\end{tabular}

Table 2.Data description for the developing countries

\begin{tabular}{|c|c|c|c|c|c|}
\hline Variable & Obs & Mean & Std. Dev & Min & $\overline{M a x}$ \\
\hline$B O D_{i t}($ kg per day $)$ & 312 & 100350.2 & 161562.5 & 1792.567 & $\overline{882985.4}$ \\
\hline$G D P_{i t}($ per capita $)$ & 312 & 2585.711 & 2424.601 & 112.5173 & 14776.9 \\
\hline$(K / L)_{i t}$ & 312 & 1758.716 & 2207.485 & 34.1354 & 16414.12 \\
\hline$T_{i t}(\%)$ & 312 & 0.820 & 0.269 & 0.292 & 1.469 \\
\hline
\end{tabular}

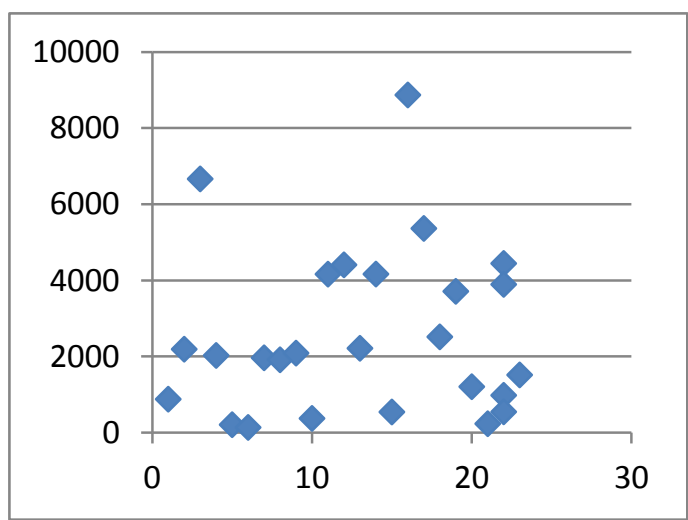

Fig (1) Average of GDP per capita for the developing countries

Considering the fragmented shape of the scatter plot (Figure 1), the countries can be evidently divided into

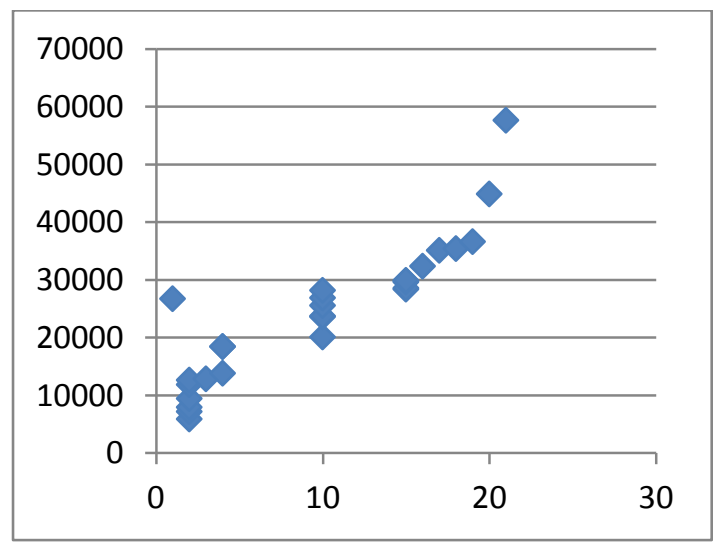

Fig (2) Average of GDP per capita for the For the developing countries

two groups of developed countries with low income (less than 20000\$) and developed countries with high 
income (more than 20000\$). To analysis the impact of region on the EKC shape, the curve are estimated for the three groups including all developed countries, developed countries with high income and developed countries with low income.
Lists of all study countries grouped in developed countries, developed countries with high income, developed countries with low income, developing countries, and coastal countries are provided in tables 3-6.

Table 3.Data description for the coastal countries

\begin{tabular}{lccccc}
\hline Variable & Obs & Mean & Std. Dev & Min & Max \\
\hline$B O D_{i t}$ & 384 & 197155.8 & 278971.4 & 1792.56 & 1453746 \\
$G D P_{i t}$ & 384 & 14382.54 & 13700.2 & 169.97 & 72959.77 \\
$(K / L)_{i t}$ & 384 & 6959.5 & 5923.73 & 70.92 & 31870.31 \\
$T_{i t}(\%)$ & 384 & 0.89 & 0.61 & 0.16 & 4.37 \\
\hline
\end{tabular}

Table 4. List of the developing countries

\begin{tabular}{ccccc}
\hline Azerbaijan & Bulgaria & Croatia & Ecuador & Eritrea \\
& & & & \\
Albany & Botswana & Ethiopia & Indonesia & Iran \\
Jordan & Kazakhstan & Kyrgyzstan & Latvia & Lithuania \\
Macedonia & Moldovan & Morris & Oman & Poland \\
Romania & South Africa & Syria & Tajikistan & Turkey \\
Yemen & & & & \\
\hline
\end{tabular}

Table 5. List of the developed countries

\begin{tabular}{|c|c|c|c|c|}
\hline Austria* & Belgium* & Canada* & Denmark* & Estonia** \\
\hline Finland* & France* & Germany* & Hungary** & Ireland* \\
\hline Italy* & Israel* & Japan* & Luxembourg* & Malta** \\
\hline Netherlands* & New Zealand* & Norway* & Portugal $* *$ & South Korea** \\
\hline Singapore* & Slovakia** & Slovenia** & Spain* & Sweden* \\
\hline United Kingdom* & United States* & Czech** Republic & & \\
\hline $\begin{array}{l}* \text { High income Countries } \\
* * \text { Low income Countries }\end{array}$ & & & & \\
\hline
\end{tabular}

Table 6. List of the coastal countries

\begin{tabular}{ccccc}
\hline Azerbaijan & Croatia & Canada & Denmark & Estonia \\
Eritrea & France & Finland & Indonesia & Ireland \\
Italy & Iran & Japan & Morris & Malta \\
New Zealand & Norway & Netherlands & Oman & Portugal \\
Singapore & South Africa & Spain & Sweden & South Korea \\
Turkey & United States & United Kingdom & & Yemen \\
\hline
\end{tabular}

Having reviewed the developing countries, many are coastal countries that, according to the literature, face the problem of seawater pollution. As the seawater pollution may affect BOD estimates, we examined the EKC relationship for the coastal countries, separately. A summary of the collected data for the described variables in the coastal countries is presented in the table 8 
Table .8: Model estimates for the developed countries

\begin{tabular}{|c|c|c|c|c|c|c|}
\hline Regressors & (1) & (2) & (3) & (4) & (5) & (6) \\
\hline$G D P_{i t}$ & $\begin{array}{l}12.72 * \\
{[0.010]}\end{array}$ & $\begin{array}{l}18.66^{*} \\
{[0.028]}\end{array}$ & $\begin{array}{l}18.53 * \\
{[0.029]}\end{array}$ & $\begin{array}{l}13.11 * \\
{[0.040]}\end{array}$ & $\begin{array}{l}12.25^{*} \\
{[0.018]}\end{array}$ & $\begin{array}{l}28.79^{*} \\
{[0.000]}\end{array}$ \\
\hline$G D P_{i t}^{2}$ & $\begin{array}{c}-0.00077 * \\
{[0.034]}\end{array}$ & $\begin{array}{c}-0.0004 * \\
{[0.044]}\end{array}$ & $\begin{array}{l}0.00005 \\
{[0.732]}\end{array}$ & $\begin{array}{c}-0.0005^{*} \\
{[0.065]}\end{array}$ & $\begin{array}{c}-0.0009^{*} \\
{[0.071]}\end{array}$ & $\begin{array}{c}-0.0003^{*} \\
{[0.000]}\end{array}$ \\
\hline$(K / L)_{i t}$ & $\begin{array}{c}10.41 \\
{[0.594]}\end{array}$ & $\begin{array}{c}21.38 \\
{[0.312]}\end{array}$ & $\begin{array}{c}19.75 \\
{[0.345]}\end{array}$ & $\begin{array}{c}13.55 \\
{[0.482]}\end{array}$ & $\begin{array}{c}15.32 \\
{[0.413]}\end{array}$ & \\
\hline$(K / L)_{i t}^{2}$ & $\begin{array}{l}0.0035 \\
{[0.382]}\end{array}$ & $\begin{array}{r}-0.0039 \\
{[0.347]}\end{array}$ & $\begin{array}{c}-0.0017 * \\
{[0.010]}\end{array}$ & $\begin{array}{r}-0.0005 \\
{[0.395]}\end{array}$ & & \\
\hline$(K / L)_{i t} G D P_{i t}$ & $\begin{array}{r}-0.0036 \\
{[0.304]}\end{array}$ & $\begin{array}{l}0.0019 \\
{[0.598]}\end{array}$ & & & $\begin{array}{r}-0.0005 \\
{[0.313]}\end{array}$ & \\
\hline$T_{i t}$ & $\begin{array}{c}- \\
291715.8 * \\
{[0.000]}\end{array}$ & & & $\begin{array}{c}-283921.9^{*} \\
{[0.000]}\end{array}$ & $\begin{array}{c}-283927.1 * \\
{[0.000]}\end{array}$ & \\
\hline Turning point & 8259.74 & 23325 & n,a. & 13110 & 6805.55 & 47983.33 \\
\hline $\begin{array}{c}\text { Elasticity for } \\
\text { GDP }\end{array}$ & 5.13 & 1.60 & 1.66 & 0.89 & 2.94 & 1.12 \\
\hline Elasticity for $\mathrm{K} / \mathrm{L}$ & 0.016 & 0.68 & 0.65 & 0.088 & 0.11 & \\
\hline Elasticity for $\mathrm{T}$ & -0.99 & & & -0.96 & -0.96 & \\
\hline $\begin{array}{l}\text { Estimation } \\
\text { technique }\end{array}$ & GLS & GLS & GLS & GLS & GLS & GLS \\
\hline $\begin{array}{l}\text { Number of } \\
\text { observations }\end{array}$ & 336 & 336 & 336 & 336 & 336 & 336 \\
\hline
\end{tabular}

Model specification: The EKC curve estimated for the groups of developing and developed counteries takes the following form $E_{i t}=c_{1}+\alpha_{1} S_{i t}+\alpha_{2} S_{i t}^{2}+\alpha_{3}(K / L)_{i t}+\alpha_{4}(K / L)_{i t}^{2}+\alpha_{5}(K / L)_{i t} S_{i t}+\alpha_{6} T_{i t}$

Where BOD (measured in per kilogram per day) indicates water pollution (biological oxegen demand) per capita of country i for the year $t$ measured. $S$ and $\mathrm{S}^{2}$ are a GDP per capita and its quadratic that are expected to measure the scale effect. (K/L) and $(\mathrm{K} / \mathrm{L}) 2$ present a country' $\mathrm{s}$ capital-labor ratio and its quadratic. The two variables are assumed to capture the impact of capital accumulation. $\mathrm{T}$ is the ratio of aggregate exports and imports to GDP that is widely used by the literature such as (Managi S., Akira H. et al. 2009) as a proxy for a country's trade openness .The variable is expected to catch the impact of trade liberalization (trade intensity) on water pollution. The $(\mathrm{K} / \mathrm{L}) \mathrm{S}$ is the composition impact of capital intensity and income on the water pollution. The variable is assumed to see if the impact of capital intensity on the water pollution can be influenced by a country's income or not. On the other words, while a country may have advantages in producing capital-intensive products it may not progress producing this type of product because of the country's regulations.
The model was initially estimated by the OLS technique. To compare the OLS estimates with the Pooled estimates, the F-Limer test was used. The test result showed that the model should be estimated by panel techniques. The Hausman test was used to evaluate the results of fixed effect model against the random effect model. However, because of the heteroscedastic results, the Generalized Least Square (GLS) was finally applied.

\section{RESULTS AND DISCUSSION}

Data description: The EKC curve was estimated for country groups described before. To compare a country group with its counterpart in the EKC shape, the results are presented in three parts including "EKC for developed and developing countries", "EKC for developed countries with high/low income" and "EKC for coastal countries".

EKC for developed and developing countries: The ttest results present that developing and developed countries differ in income per capita and pollution levels of BOD, statistically (table 7). 
Table7. The T-test to compare means

\begin{tabular}{|c|c|c|c|c|}
\hline $\begin{array}{l}\text { Groups of study } \\
\text { countries }\end{array}$ & $\begin{array}{l}\text { Mean Difference } \\
\text { In GDP }\end{array}$ & $\mathrm{t}$ & $\begin{array}{l}\text { Mean Difference } \\
\text { In BOD }\end{array}$ & $\mathrm{t}$ \\
\hline $\begin{array}{c}\text { Developed and } \\
\text { Developing countries }\end{array}$ & 21794.21 & $\begin{array}{l}29.6313 \\
(0.0000)\end{array}$ & 224959.3 & $\begin{array}{c}7.5422 \\
(0.0000)\end{array}$ \\
\hline developed countries with high and low income & -22945.47 & $\begin{array}{l}-17.6414 \\
(0.0000)\end{array}$ & -229693 & $\begin{array}{l}-5.4707 \\
(0.0000)\end{array}$ \\
\hline developing countries with high and low income & 21794.209 & $\begin{array}{c}-14.69 \\
(0.0000)\end{array}$ & 46072.94 & $\begin{array}{c}1.963 \\
(0.052)\end{array}$ \\
\hline
\end{tabular}

The figures 3 and 4 plot income per capita against BOD for the two groups of developed and developing countries, respectively. For the developed countries (Figure3), the inverted-U shape of EKC is evident. For the developing countries (Figure4), the EKC

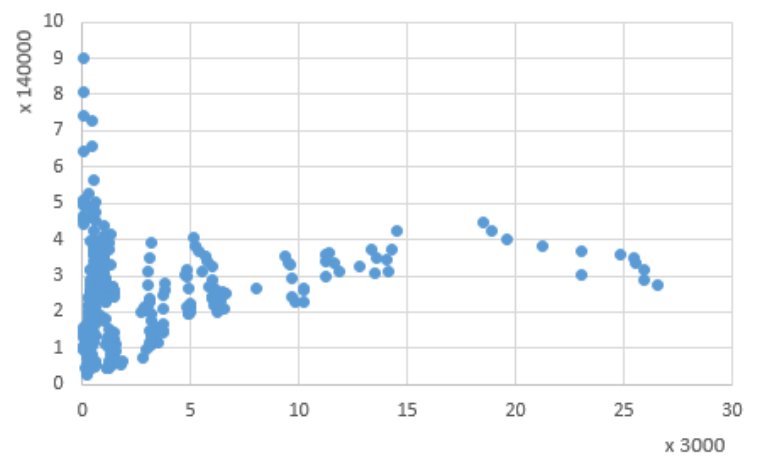

Fig 3. The relationship between the GDP and the BOD For the developed countries

The estimates of the GLS model are presented in the table 8 and table 9 for the developed countries and developing countries, separately. The significant positive relationship between $\mathrm{S}$ and BOD and the negative relationship between $S^{2}$ and BOD confirm the U-inverted shape of EKC curve for both developed and developing countries. However, the curve appears a positive relationship between BOD and income per capita for countries on the left-side of the figure (with less income), but eventually the relationship becomes negative as the country's income per capita approaches to $4000 \$$ and more

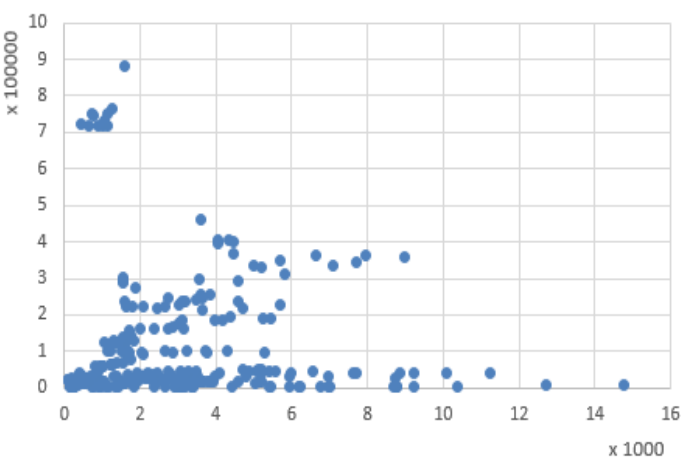

Fig 4. The relationship between the GDP and the BOD for the developing countries

two groups of countries differs in the turning point of the EKC curve that is about 23325 \$ -below their average income per capita at $23325 \$$ - for the developed countries and around $5000 \$$ - beyond their average income per capita at $3195.91 \$$ - for the developing countries

Table 9. Model estimates for the developing countries

\begin{tabular}{|c|c|c|c|c|c|c|}
\hline Regressors & (1) & (2) & (3) & (4) & (5) & (6) \\
\hline$G D P_{i t}$ & $\begin{array}{c}36.1 \\
07^{*} \\
{[0.0} \\
02]\end{array}$ & $\begin{array}{l}31.32^{*} \\
{[0.011]}\end{array}$ & $\begin{array}{l}25.80 * \\
{[0.022]}\end{array}$ & $\begin{array}{l}27.80^{*} \\
{[0.008]}\end{array}$ & $\begin{array}{l}37.43^{*} \\
{[0.001]}\end{array}$ & $\begin{array}{l}23.29 * \\
{[0.013]}\end{array}$ \\
\hline$G D P_{i t}^{2}$ & $\begin{array}{c}- \\
0.00 \\
59^{*} \\
{[0.0} \\
16]\end{array}$ & $\begin{array}{c}-0.0049 * \\
{[0.066]}\end{array}$ & $\begin{array}{c}-0.0021 * \\
{[0.029]}\end{array}$ & $\begin{array}{c}-0.0018^{*} \\
{[0.043]}\end{array}$ & $\begin{array}{c}-0.0057 * \\
{[0.017]}\end{array}$ & $\begin{array}{c}-0.0022 * \\
{[0.015]}\end{array}$ \\
\hline$(K / L)_{i t}$ & $\begin{array}{c}- \\
23.2 \\
01 * \\
{[0.0} \\
91]\end{array}$ & $\begin{array}{c}-10.26 \\
{[0.485]}\end{array}$ & $\begin{array}{r}-7.005 \\
{[0.627]}\end{array}$ & $\begin{array}{r}-18.099 \\
{[0.179]}\end{array}$ & $\begin{array}{r}-27.29 * \\
{[0.002]}\end{array}$ & \\
\hline$(K / L)_{i t}^{2}$ & $\begin{array}{c}- \\
0.00 \\
043 \\
{[0.7]}\end{array}$ & $\begin{array}{r}-0.0007 \\
{[0.557]}\end{array}$ & $\begin{array}{c}-0.00019 \\
{[0.863]}\end{array}$ & $\begin{array}{c}0.00033 \\
{[0.752]}\end{array}$ & & \\
\hline
\end{tabular}




\begin{tabular}{|c|c|c|c|c|c|c|}
\hline$(K / L)_{i t} G D P_{i t}$ & $\begin{array}{c}0.00 \\
66^{*} \\
{[0.0} \\
72]\end{array}$ & $\begin{array}{l}0.0044 \\
{[0.264]}\end{array}$ & & & $\begin{array}{l}0.0061^{*} \\
{[0.0074]}\end{array}$ & \\
\hline$T_{i t}$ & $\begin{array}{c}- \\
208 \\
891 . \\
8^{*} \\
{[0.0} \\
00]\end{array}$ & & & $\begin{array}{c}-204627.2 * \\
{[0.000]}\end{array}$ & $\begin{array}{c}-209273.1 * \\
{[0.000]}\end{array}$ & \\
\hline Turning point & $\begin{array}{l}305 \\
9.91\end{array}$ & 3195.9 & 6142.85 & 7722.22 & 3283.33 & 5293.18 \\
\hline Elasticity for GDP & 0.44 & 0.35 & 0.38 & 0.47 & 0.48 & 0.306 \\
\hline Elasticity for $\mathrm{K} / \mathrm{L}$ & $\begin{array}{c}- \\
0.13\end{array}$ & -0.023 & -0.13 & -0.29 & -0.201 & \\
\hline Elasticity for $\mathrm{T}$ & $\overline{-}$ & & & -1.7 & -1.73 & \\
\hline $\begin{array}{l}\text { Estimation } \\
\text { technique }\end{array}$ & GLS & GLS & GLS & GLS & GLS & GLS \\
\hline $\begin{array}{l}\text { Number of } \\
\text { observations }\end{array}$ & 312 & 312 & 312 & 312 & 312 & 312 \\
\hline
\end{tabular}

For both developed and developing countries, according to the three GLS models the impact of a country's capital-to-labor ratio on BOD is statistically insignificant, while it is negative based on the three other models.

For both developed and developing countries, the GLS models estimate a negative impact of trade openness on the BOD, and an insignificant impact of the composition effect of K/L and GDP on the BOD.

On the bottom of the two tables, sample-mean elasticitis of BOD to an increase in the explanatory factors are presented. For the developed countries, BOD elasticity for an increase in GDP is estimated between 5.13 and 0.89 by the six models. BOD elasticity for $\mathrm{T}$ was measured around 1.04. For the developing countries, elasticities of BOD for an increase in GDP and T are estimated around 0.4 and 1.7 .

EKC for developed countries with low/high income: The t-test results indicate that the sub- groups of low income and high income countries within the main group of developed countries are statistically different in terms of income per capita and pollution level of BOD (table 7).

According to the results obtained from GLS estimates (Table 10and 11), the two variables of $\mathrm{S}$ and $S^{2}$ have a positive and negative relations with the BOD for the countries with high income, while both relations are insignificant for the countries with low income. Accordingly, the EKC shape are confirmed for countries with high income, while the shape was rejected for the countries with low income

Table10. Model estimates for the developed countries with high income

\begin{tabular}{|c|c|c|c|c|c|c|}
\hline Regressors & (1) & (2) & (3) & (4) & (5) & (6) \\
\hline$G D P_{i t}$ & $\begin{array}{l}26.17 * \\
{[0.064]}\end{array}$ & $\begin{array}{l}38.99 * \\
{[0.010]}\end{array}$ & $\begin{array}{l}37.29 * \\
{[0.013]}\end{array}$ & $\begin{array}{l}27.53 * \\
{[0.048]}\end{array}$ & $\begin{array}{l}26.41 * \\
{[0.062]}\end{array}$ & $\begin{array}{l}41.07^{*} \\
{[0.000]}\end{array}$ \\
\hline$G D P_{i t}^{2}$ & $\begin{array}{c}-0.0003^{*} \\
{[0.043]}\end{array}$ & $\begin{array}{c}-0.0010^{*} \\
{[0.016]}\end{array}$ & $\begin{array}{c}-0.0002^{*} \\
{[0.057]}\end{array}$ & $\begin{array}{c}-0.00026^{*} \\
{[0.020]}\end{array}$ & $\begin{array}{c}-0.0002^{*} \\
{[0.059]}\end{array}$ & $\begin{array}{c}-0.0004^{*} \\
{[0.000]}\end{array}$ \\
\hline$(K / L)_{i t}$ & $\begin{array}{c}1.307 \\
{[0.966]}\end{array}$ & $\begin{array}{l}-8.31 \\
{[0.803]}\end{array}$ & $\begin{array}{c}-10.84 \\
{[0.744]}\end{array}$ & $\begin{array}{c}2.74 \\
{[0.929]}\end{array}$ & $\begin{array}{c}5.61 \\
{[0.851]}\end{array}$ & \\
\hline$(K / L)_{i t}^{2}$ & $\begin{array}{l}0.0027 \\
{[0.572]}\end{array}$ & $\begin{array}{r}-0.004 \\
{[0.330]}\end{array}$ & $\begin{array}{c}0.0008 \\
{[0.416]}\end{array}$ & $\begin{array}{c}-0.00009 \\
{[0.924]}\end{array}$ & & \\
\hline$(K / L)_{i t} G D P_{i t}$ & $\begin{array}{r}-0.0025 \\
{[0.551]}\end{array}$ & $\begin{array}{c}0.0037 \\
{[0.407]}\end{array}$ & & & $\begin{array}{c}-0.00017 \\
{[0.834]}\end{array}$ & \\
\hline
\end{tabular}




\begin{tabular}{|c|c|c|c|c|c|c|}
\hline$T_{i t}$ & $\begin{array}{c}-299249.8 \\
{[0.000]}\end{array}$ & & & $\begin{array}{c}-292978.2^{*} \\
{[0.000]}\end{array}$ & $\begin{array}{c}-292812.6^{*} \\
{[0.000]}\end{array}$ & \\
\hline Turning point & 43616.66 & 19495 & 93225 & 52942.3 & 66025 & 51337.5 \\
\hline Elasticity for GDP & 1.94 & 2.18 & 1.95 & 0.92 & 0.93 & 1.31 \\
\hline Elasticity for $\mathrm{K} / \mathrm{L}$ & 0.057 & -0.13 & 0.36 & 0.011 & 0.017 & \\
\hline Elasticity for $\mathrm{T}$ & -0.76 & & & -0.74 & -0.74 & \\
\hline $\begin{array}{l}\text { Estimation } \\
\text { technique }\end{array}$ & GLS & GLS & GLS & GLS & GLS & GLS \\
\hline $\begin{array}{l}\text { Number of } \\
\text { observations }\end{array}$ & 240 & 240 & 240 & 240 & 240 & 240 \\
\hline
\end{tabular}

Table 11. Model estimates for the developed countries with low income

\begin{tabular}{|c|c|c|c|c|c|c|}
\hline Regressors & (1) & (2) & (3) & (4) & (5) & (6) \\
\hline $\mathrm{GDP}_{\text {it }}$ & $\begin{array}{c}0.454 \\
{[0.776]}\end{array}$ & $\begin{array}{c}0.52 \\
{[0.821]}\end{array}$ & $\begin{array}{c}0.49 \\
{[0.834]}\end{array}$ & $\begin{array}{c}0.458 \\
{[0.775]}\end{array}$ & $\begin{array}{c}0.46 \\
{[0.775]}\end{array}$ & $\begin{array}{c}0.77 \\
{[0.766]}\end{array}$ \\
\hline $\mathrm{GDP}_{\mathrm{it}}^{2}$ & $\begin{array}{r}-0.0007 \\
{[0.503]}\end{array}$ & $\begin{array}{c}-0.0013 \\
{[0.394]}\end{array}$ & $\begin{array}{c}-0.0007 * \\
{[0.000]}\end{array}$ & $\begin{array}{c}-0.0007^{*} \\
{[0.000]}\end{array}$ & $\begin{array}{c}-0.0017^{*} \\
{[0.000]}\end{array}$ & 0.00013 [0.382] \\
\hline$(\mathrm{K} / \mathrm{L})_{\mathrm{it}}$ & $\begin{array}{l}-7.81 \\
{[0.539]}\end{array}$ & $\begin{array}{c}3.86 \\
{[0.834]}\end{array}$ & $\begin{array}{c}3.51 \\
{[0.849]}\end{array}$ & $\begin{array}{l}-7.78 \\
{[0.540]}\end{array}$ & $\begin{array}{l}-4.16 \\
{[0.732]}\end{array}$ & \\
\hline$(\mathrm{K} / \mathrm{L})_{\mathrm{it}}^{2}$ & $\begin{array}{l}0.0034 \\
{[0.340]}\end{array}$ & $\begin{array}{l}0.0011 \\
{[0.823]}\end{array}$ & $\begin{array}{l}0.0031 * \\
{[0.034]}\end{array}$ & $\begin{array}{l}0.0032 * \\
{[0.001]}\end{array}$ & & \\
\hline$(\mathrm{K} / \mathrm{L})_{\mathrm{it}} \mathrm{GDP}_{\mathrm{it}}$ & $\begin{array}{c}-0.00019 \\
{[0.960]}\end{array}$ & $\begin{array}{l}0.0021 \\
{[0.703]}\end{array}$ & & & $\begin{array}{c}0.0033^{*} \\
{[0.002]}\end{array}$ & \\
\hline $\mathrm{T}_{\mathrm{it}}$ & $-180152.2 *[0.000]$ & & & $\begin{array}{c}-180102.4^{*} \\
{[0.000]}\end{array}$ & $\begin{array}{c}-179159.4^{*} \\
{[0.000]}\end{array}$ & \\
\hline Turning point & n,a. & $\mathrm{n}, \mathrm{a}$. & n,a. & n.a. & n,a. & n,a. \\
\hline Elasticity for GDP & 1.48 & 1.43 & 1.37 & 1.37 & 1.59 & 0.34 \\
\hline Elasticity for $\mathrm{K} / \mathrm{L}$ & 1.48 & 2.01 & 2.02 & -1.47 & -1.58 & \\
\hline Elasticity for $\mathrm{T}$ & -2.07 & & & -2.07 & -2.06 & \\
\hline Estimation technique & GLS & GLS & GLS & GLS & GLS & GLS \\
\hline Number of observations & 96 & 96 & 96 & 96 & 96 & 96 \\
\hline
\end{tabular}

Having the countries located in the two sub-groups of the developed countries reviewed; it became evident that many are coastal countries dealing with the problem of seawater pollution. To examine the hypothesis, an EKC curve for the coastal countries of the sample was estimated and presented in the part „c“. The turning point of the EKC curve for the developed countries with high income appears around $55000 \$$ that is very far from the average income of thoes countries at $30011.72 \$$. The impact of the capital-and-labour ratio on the BOD was estimated insignificant for both countries with high income and countries with low income. The impact of the trade openess on the BOD is negative for both countries with high income and low income.

For the countries with high income, BOD elasticities for GDP and T are around 1.5, and -0.7 , respectively. For the developed countries with low income, the BOD elasticities for GDP, K/L and T are around 1.4, and -2 , respectively.

EKC for coastal countries: For coastal countries, the results obtained from estimating the model(Table 12) confirm the inverted-U shape EKC curve, however with a very high turning point at about 25518 dollars. Comparing the turning point with the average 
income, it is concluded that the coastal countries are still on the upward part and very far from the turning point on the EKC curve. The similar results obtained for the impact of $\mathrm{K} / \mathrm{L}$ ratio and $\mathrm{T}$ on the BOD.

Table 12. Model estimates for the coastal countries

\begin{tabular}{|c|c|c|c|c|c|c|}
\hline Regressors & (1) & (2) & (3) & (4) & (5) & (6) \\
\hline$\overline{G D P_{i t}}$ & $\begin{array}{l}20.75^{*} \\
{[0.000]}\end{array}$ & $\begin{array}{l}19.55^{*} \\
{[0.002]}\end{array}$ & $\begin{array}{l}24.71^{*} \\
{[0.000]}\end{array}$ & $\begin{array}{l}28.07 * \\
{[0.000]}\end{array}$ & $\begin{array}{l}22.24^{*} \\
{[0.000]}\end{array}$ & $\begin{array}{l}14.14^{*} \\
{[0.000]}\end{array}$ \\
\hline$G D P_{i t}^{2}$ & $\begin{array}{c}-0.0009^{*} \\
{[0.000]}\end{array}$ & $\begin{array}{c}-0.0006^{*} \\
{[0.001]}\end{array}$ & $\begin{array}{c}-0.00043^{*} \\
{[0.000]}\end{array}$ & $\begin{array}{c}-0.00057^{*} \\
{[0.000]}\end{array}$ & $\begin{array}{c}-0.00087 * \\
{[0.000]}\end{array}$ & $\begin{array}{c}-0.00018^{*} \\
{[0.001]}\end{array}$ \\
\hline$(K / L)_{i t}$ & $\begin{array}{c}-12.04 \\
{[0.365]}\end{array}$ & $\begin{array}{c}-14.87 \\
{[0.324]}\end{array}$ & $\begin{array}{r}-27.42^{*} \\
{[0.019]}\end{array}$ & $\begin{array}{c}-29.91 * \\
{[0.004]}\end{array}$ & $\begin{array}{c}-15.75^{*} \\
{[0.025]}\end{array}$ & \\
\hline$(K / L)_{i t}^{2}$ & $\begin{array}{c}-0.00039 \\
{[0.743]}\end{array}$ & $\begin{array}{r}-0.0002 \\
{[0.860]}\end{array}$ & $\begin{array}{c}-0.0014 * \\
{[0.009]}\end{array}$ & $\begin{array}{l}0.0019^{*} \\
{[0.000]}\end{array}$ & & \\
\hline$(K / L)_{i t} G D P_{i t}$ & $\begin{array}{c}0.0017 * \\
{[0.035]}\end{array}$ & $\begin{array}{c}0.0012 \\
{[0.191]}\end{array}$ & & & $\begin{array}{c}0.0015^{*} \\
{[0.000]}\end{array}$ & \\
\hline$T_{i t}$ & $\begin{array}{c}-202497.1^{*} \\
{[0.000]}\end{array}$ & & & $\begin{array}{c}-200025.3^{*} \\
{[0.000]}\end{array}$ & $\begin{array}{c}-202418.9 \\
{[0.000]}\end{array}$ & \\
\hline Turning point & 11527.7 & 16291.6 & 28732.5 & 25518.18 & 13082.3 & 39277.7 \\
\hline Elasticity for GDP & 0.49 & 0.77 & 0.6 & 0.85 & 0.55 & 0.65 \\
\hline Elasticity for $\mathrm{K} / \mathrm{L}$ & -0.24 & -0.013 & -1.65 & -0.12 & -0.2 & \\
\hline Elasticity for $\mathrm{T}$ & -0.91 & & & -0.9 & -0.91 & \\
\hline $\begin{array}{c}\text { Estimation } \\
\text { technique }\end{array}$ & GLS & GLS & GLS & GLS & GLS & GLS \\
\hline $\begin{array}{l}\text { Number of } \\
\text { observations }\end{array}$ & 384 & 384 & 384 & 384 & 384 & 384 \\
\hline
\end{tabular}

Conclusion: Results confirm the inverted-U shape EKC for all groups of developed and developing countries, except for developed countries with low income. The results presented a positive relationship between GDP and BOD for the group of developed countries with low income. Since many of the developed countries with low income are partly bounded by either sea or ocean, it can be expected that the EKC shape have been influenced by seawater pollutions. We, accordingly, examined the EKC relationship for all coastal countries in our sample. The results confirmed the inverted-U shape EKC curve, however with a high-income turning point that is very far from the average of GDP per capita for those countries. This can be concluded that increases in income of the coastal countries is raising water pollution.

Although the EKC shape was confirmed for both the developed countries and the developing countries, the actual relationship depends on the point at which the countries stand.The results related to turning point estimates indicate that the developed countries are in the downward part of the EKC curve, while the developing countries are on the upwards. It can be concluded that water pollution are decreased by increasing incomes in the developed countries, while in the developing countries increasing income still raises the water pollution. This is much more evident for the developed countries with high income whose income per capita is quite far from the turning point of the EKC curve. Accordingly, economic growth certainly progresses environmental quality in the developed countries with high income. This result should be , with more caution, translated into the developed countries with low income. Ultimately, under the current circumstances, economic growth progresses environmental quality in the developed countries in particular the developed countries with high income, while it causes damage to the developing countries and most probably in the developed countries with low income.

Contrary to many studies (Managi and Akira, 2009), the composition effect concluded from the estimated coefficient for the capital labor ratio does not have a great influence on the water pollution.

For all study countries, the trade openness increases magnitude of water pollution. This can be concluded that almost all countries intend to produce dirty goods, in case of trade liberalization. On the other words, most countries require their regulations on trading products to be reviewed and revised for effective restrictions on exchanging dirty products.

According to the results of BOD elasticity, for the developing countries the GDP is the most influential factor on the water pollution. For the developed countries, the BOD elasticity for GDP is estimated quite differently by the six models, ranging from 5.13 to 0.89 . This may be the result of the huge gap among the developed countries in terms of their GDP. For the developed countries with high income, the GDP plays the most influential role in the BOD magnitude, while for the countries with low income the $\mathrm{K} / \mathrm{L}$ ratio and the trade openness would strongly influence the BOD. 


\section{REFERENCES}

Antweiler W., Copeland B. (2001). "Is free trade good for the environment?, ." American Economics Review 91(4): 877-908.

Beron J.K., Murdoch C.J. (2003). "Why cooperate? Public goods, economic power, and the Montreal protocol." The Review of Economics and Statistics 85(2): 286-297.

Chien-Chiang L., Yi-Bin C. (2010). "The environmental Kuznets curve hypothesis for water pollution: Do regions matter?" Energy Policy 38(1): 12-23.

Cole, M. A. (2004). "Trade, the pollution haven hypothesis and the environmental Kuznets curve: examining the linkages." Ecological Economics 48(1): 71-81.

Cole, M. A. and R. J. R. Elliott. (2003). "Determining the trade-environment composition effect: the role of capital, labor and environmental regulations." Journal of Environmental Economics and Management 46(3): 363-383.
Grossman G. and Krueger A. E. (1995). "Economic growth and the environment." Quarterly Journal of Economics 110(2): 353-377.

Managi S., Akira H. (2009). "Does trade openness improve environmental quality?" Journal of Environmental Economics and Management 58(3): 346-363.

Panayotou T. (1993). Empirical tests and policy analysis of environmental degradation at different stages of economic development. Technology and employment programme, working paper series, Geneva: International Labor Office.

Stern D. (2004). "Environmental Kuznets Curve." Encyclopedia of Energy 2: 517-525.

Thompson A. (2014). "Environmental Kuznets Curve for Water Pollution: The Case of Border Countries." Modern Economy 5: 66-69. 